\title{
Congenital Skin Aplasia
}

Aida Zečkanović, Sandra Cerar

\section{Izvleček}

Prirojena aplazija kože (PAK) je redka prirojena nepravilnost, za katero je značilna odsotnost kože, kožnih priveskov ali podkožnih struktur na določenem delu telesa ob rojstvu in se lahko kaže kot ulceracija, membranozna sprememba ali atrofična brazgotina. Spremembe pri PAK so lahko izolirane ali v povezavi $z$ drugimi prirojenimi nepravilnostmi. $\checkmark$ približno $20 \%$ so prizadete globoke anatomske strukture (podkožno maščevje, mišice, kosti in možganske ovojnice). Najpogostejša lokacija je skalp. Čeprav so spremembe pogosto solitarne in omejene na zgornje plasti kože, so najhujše oblike PAK skalpa zaradi možnih okužb in krvavitev. povezane $z$ visoko smrtnostjo. Etiologija in patogeneza nista v celoti razjasnjeni. PAK razdelimo $v$ devet kliničnih skupin (klasifikacija po Friednu). Glede na značilnosti in pridružene nepravilnosti postavimo diagnozo in pristopimo k zdravljenju. Zdravljenje je $v$ večini primerov konzervativno, glede na kompleksnost bolezni pa ga lahko dopolnimo s kirurškim zdravljenjem. $V$ prispevku predstavljamo primer novorojenčka s PAK.

Ključne besede: prirojena aplazija kože, prirojene nepravilnosti, novorojenček, vzroki, klasifikacija, zdravljenje.

\begin{abstract}
Congenital skin aplasia (Aplasia cutis congenita - ACC) is part of a heterogeneous group of conditions characterised by the congenital absence of the epidermis, dermis, and in some cases, subcutaneous tissues, muscles, meninges, or bone, usually involving the scalp vertex. It may present as ulceration, membranous change, or an atrophic scar. ACC can occur as an isolated defect or can be associated with other congenital anomalies. In patients with large scalp and skull defects, there is an increased risk of infection and bleeding along with increased mortality and therefore prompt and effective management is advised. Its aetiology and pathogenesis remain unclear. We discuss the different types of ACC (Frieden's classification system) and associated anomalies along with an approach to diagnosis and management, which is usually conservative. The authors present a case report of a neonate with ACC due to fetus papyraceus.
\end{abstract}

Key words: aplasia cutis congenita, congenital anomalies, neonate, aetiology, classification, treatment. 


\begin{tabular}{ll}
\hline Skupina 1 & PAK na skalpu, brez pridruženih anomalij \\
\hline Skupina 2 & PAK na skalpu s pridruženimi malformacijami udov (Adams-Oliverjev sindrom) \\
\hline Skupina 3 & PAK, povezana organoidnimi nevusi (nastanejo iz enega od kožnih adneksov) \\
\hline Skupina 4 & $\begin{array}{l}\text { PAK, povezana z napako v embrionalnem razvoju (meningokela, gastroshiza, } \\
\text { omfalokela) }\end{array}$ \\
\hline Skupina 5 & $\begin{array}{l}\text { PAK, povezana z znotrajmaterničnim odmrtjem dvojčka (lat. fetus papyraceus) } \\
\text { ali infarktom posteljice }\end{array}$ \\
\hline Skupina 6 & PAK, povezana z bulozno epidermolizo \\
\hline Skupina 7 & PAK, omejena na ude brez bulozne epidermolize \\
\hline Skupina 8 & PAK, povzročena s specifičnimi teratogeni \\
\hline Skupina 9 & PAK, povezana z malformacijskimi sindromi \\
\hline
\end{tabular}

TABELA 1. KLASIFIKACIJA PRIROJENE APLAZIJE KOŽE (PAK) PO FRIEDENU (4). TABLE 1. FRIEDEN'S CLASSIFICATION OF APLASIA CUTIS (4).

\section{Uvod}

Prirojena aplazija kože (angl. aplasia cutis congenita, ACC) je redka prirojena nepravilnost, za katero je značilna odsotnost kože, kožnih priveskov ali celo podkožnih struktur na določenem delu telesa (1,2). Pojavnost prirojene aplazije kože (PAK) ocenjujejo na 0,5 do 3 primerov na 10.000 živorojenih otrok $(1,2)$, vendar je verjetno še mnogo višja, saj je večina primerov blagih in jih pogosto ne prepoznamo (3). Kaže se namreč lahko tudi kot ulceracija, membranozna sprememba ali kot atrofična brazgotina $(2,3)$.

PAK približno dvakrat pogosteje prizadene deklice. Najpogostejše mesto je skalp (84\%) (1-4). Običajno so spremembe solitarne (> $80 \%$ ) in omejene na zgornje plasti kože. Le v 15-20 \% so pri PAK na skalpu prizadete tudi spodaj ležeče anatomske strukture (podkožno maščevje, kost, možganske ovojnice) (5).

Patofiziologija PAK še ni popolnoma jasna. Obstaja več teorij o vzro- ektopičnega nevralnega tkiva $(6,7)$. Kazalnik prisotnosti ektopičnega tkiva in spinalnega disrafizma je lasni obroč okrog kožnega defekta. To je obroba iz las, ki so lahko bolj grobi, debelejši in daljši od normalnih las. Ločitev epitelnega in nevralnega ektoderma na skalpu se zgodi hkrati z zapiranjem nevralne cevi med 3. in 5. tednom nosečnosti. Pri teh oblikah PAK so zato pogosto prisotni encefalokele, meningokele in ektopično možgansko tkivo. Tudi histološke značilnosti membranozne in bulozne PAK so podobne meningokeli. Pri bulozni ali membranozni PAK, ki se nahaja v srednji liniji skalpa ali ima lasni obroč, moramo zato opraviti magnetnoresonančno slikanje (MRI) glave, da izključimo ektopično živčno tkivo (1,6-8).

Nemembranozna PAK na skalpu pa naj bi po drugi strani nastala na predelu kože, kjer so tenzijske sile med rastjo možganov najmočnejše in povzročijo razmik kožnega tkiva. Ti defekti zato najpogosteje nastanejo ob verteksu. Zanje je značilna bolj nepravilna oblika z nazobčanimi robovi. Nemembranozna oblika je pogosteje dedna, zato sta pri novorojenčkih s to obliko PAK pomembni družinska anamneza in skrbna ocena pridruženih anomalij, ki bi nakazovale na sindromsko obliko PAK (1). Da izključimo Adams-Oliverjev sindrom, moramo vedno oceniti malformacije udov (1).

Opisujejo tudi številne izolirane prirojene nepravilnosti, ki se pojavljajo v povezavi z nesindromsko PAK na skalpu. Mednje uvrščamo ušesne malformacije, kolobom, glavkom, razcepe ustnice in ustnega neba, odsotnost nosnega pretina, atrezijo hoan, laringomalacijo, srčne napake, umbilikalne kile, ledvične nepravilnosti, kriptorhizem in nediferencirano spolovilo (3). defektov, ki se nahajajo na skalpu in so ob rojstvu pokriti z nežno membrano (membranozna PAK). Če se pod membrano nabere serozna tekočina ali celo kri, gre za bulozno PAK. Po eni izmed teorij so tovrstne kožne spremembe posledica nepravilnega zapiranja ektodermalnih fuzijskih linij in prisotnosti

\section{Adams-Oliverjev sindrom}

Veliki nemembranozni kožni defekti na skalpu se lahko pojavljajo v sklopu Adams-Oliverjevga sindroma (AOS) 
(9). AOS je redka prirojena bolezen, pri kateri je v $75 \%$ prisoten nemembranozni PAK na verteksu skalpa v povezavi $z$ deformacijami udov. Pri njihovi oceni je potrebna previdnost, saj so lahko subtilne, na primer odsoten noht ali razširjena konica prsta (1). Najpogosteje se pojavljajo brahidaktilija (kratki prsti), sindaktilija, odsotne distalne falange in odsotnost prsta, roke, stopala ali celega uda. Redkeje sta pridruženi še Polandova sekvenca (enostranska hipoplazija uda in prsnih mišic) ali asimetrija obraza $(1,3)$. Malformacije udov pri AOS so asimetrične in pogosteje prizadenejo spodnje ude $(1,10)$. Pri diagnosticiranju si pomagamo tudi z rentgenskim slikanjem (RTG) udov (1).

Ob postavitvi diagnoze AOS ali sumu na AOS je potrebna natančna ocena srčno-žilnega, prebavnega in živčnega sistema, saj so pridružene anomalije prisotne pri četrtini bolnikov (1). Najdemo lahko cutis marmorata telangiectatica congenita (CMTC), spastičnost, difuzno počasno aktivnost na elektroencefalogramu, možganske kalcinacije, polimikrogirijo, mikrocefalijo, epilepsijo, razvojni zaostanek, hidrocefalus in Dandy-Walkerjevo malformacijo. Srčne napake ugotavljamo pri $20 \%$ bolnikov, najpogosteje membranozno subaortno stenozo, pulmonalno stenozo, defekt pretina prekatov, defekt pretina preddvorov, Fallotovo tetralogijo, koarktacijo aorte, bikuspidalno aortno zaklopko, pljučno hipertenzijo in desni prekat $z$ dvojnim iztokom $(1,10)$. V sklopu tega sindroma opisujejo razcep ustnice, dodatne prsne bradavice, redkeje zastoj rasti, kratke palpebralne fisure, razširjene vene skalpa, kriptorhizem, hemangiome, mikroftalmijo in hipoplastični optični živec $(1,10)$.

Etiologija AOS še ni dokončno pojasnjena. Deduje se večinoma avtosomno dominantno z nepopolno penetranco. Opisujejo tudi sporadične primere $(1,11)$. Do sedaj je opisanih šest genov, povezanih z AOS. Dva sta del poti CDC42/RAC1, štirje pa sodelu-

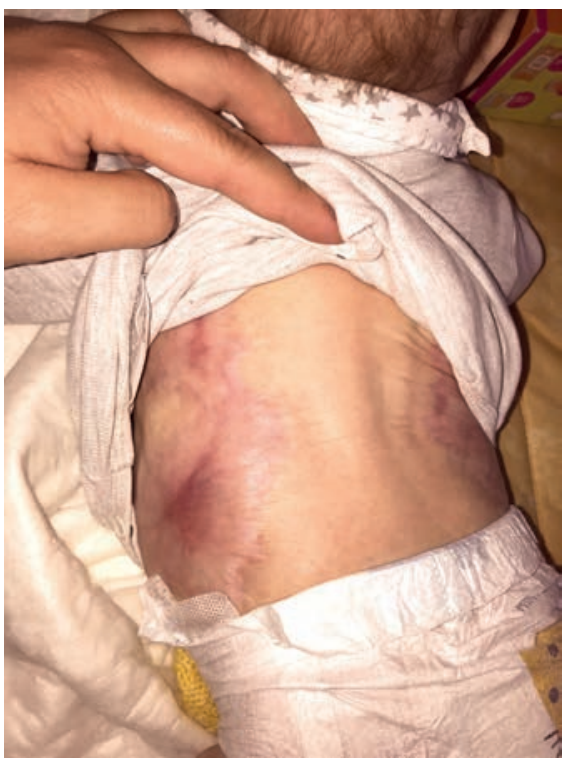

SLIKA 4. BOLNIK V STAROSTI 4 TEDNE Z LEZIJO NA HRBTU.

FIGURE 4. PATIENT AT THE AGE OF 4 WEEKS WITH A BACK LESION.

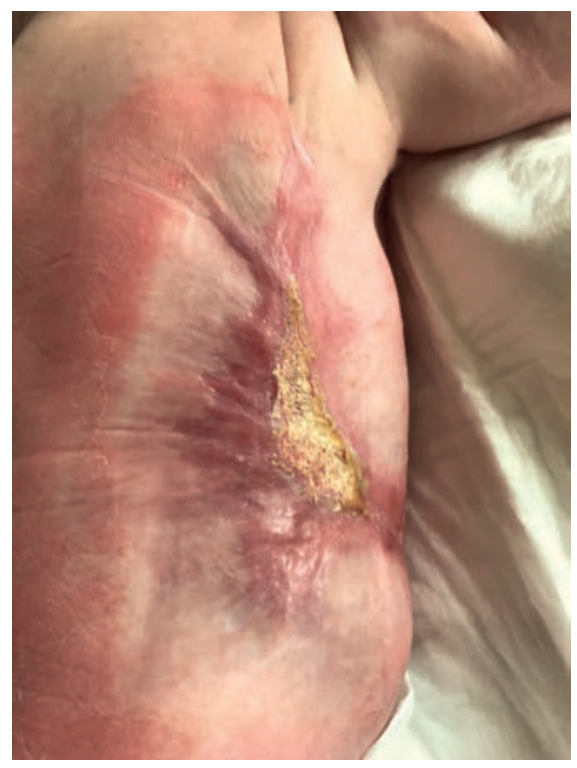

SLIKA 5. BOLNIK V STAROSTI 3 MESECE Z LEZIJO NA HRBTU.

FIGURE 5. PATIENT AT THE AGE OF 3 MONTHS WITH A BACK LESION.

\begin{tabular}{lr}
\hline Predel telesa & Pogostost (\%) \\
\hline bok & 70 \\
\hline glutealni predel, stegno & 60 \\
\hline trebuh & 33 \\
\hline skalp & 26 \\
\hline pazduha, zgornji udi & 21 \\
\hline hrbet & 16 \\
\hline
\end{tabular}

TABELA 2. RAZPOREDITEV SPREMEMB PAK KOT POSLEDICA ZNOTRAJMATERNIČNEGA ODMRTJA ENEGA OD DVOJČKOV (17).

TABLE 2. APLASIA CUTIS CONGENITA TYPE 5 (FETUS PAPYRACEUS), DISTRIBUTION OF AFFECTED BODY AREAS (17) 
jejo $v$ signalni poti NOTCH $(A R H-$ GAP31, DOCK6, RBPJ, EOGT, NOTCH1, $D L L 4)(10,12)$. Signalna pot NOTCH je pomembna med embrionalnim razvojem srčno-žilnega sistema in udov. Mutacije gena NOTCH1 so pogosteje povezane s priduženimi prirojenimi srčnimi napakami (12). Verjeten mehanizem nastanka so motnje prekrvitve ali znotrajmaternični trombotični dogodki. $V$ eni od teorij nastanek AOS povezujejo tudi z motnjo v delovanju pericitov, celic, ki so potrebne za oblikovanje malih žil (13).

Ob sumu na AOS je priporočeno genetsko svetovanje družini, v naslednji nosečnosti pa zgodnje odkrivanje malformacij udov z ultrazvočnim pregledom v 16. tednu nosečnosti (1). Med nosečnostjo imajo matere otrok $\mathrm{S}$ PAK povišan alfa-fetoprotein $v$ serumu in amnijski tekočini ter povišano amnijsko acetilholinesterazo, vendar te značilnosti niso specifične za PAK $(14,15)$.

Za kostne deformacije je potrebna obravnava pri ortopedu (1).

\section{Znotrajmaternični vzroki PAK (lat. fetus papyraceus)}

Po klasifikaciji sodijo bolniki z navedenimi značilnostmi v skupino 5 . PAK na trupu se pogosto pojavljajo $v$ povezavi z znotrajmaterničnim odmrtjem enega izmed dvojčkov, pri čemer gre v $95 \%$ za monohorionske dvojčke (16). Do odmrtja pride $v$ drugi polovici prvega ali prvi polovici drugega trimesečja nosečnosti (1). $V$ tej nosečnostni starosti ne pride do popolne resorpcije ploda kot pri zelo zgodnjih splavih, niti ni potrebna kirurška odstranitev ploda kot pri poznih splavih. Zaradi pritiska na odmrli plod pride med rastjo preživelega dvojčka do sploščitve ob maternično steno in mumifikacije ploda $(16,17)$.

Za to obliko PAK so značilne velike simetrične kožne lezije na trupu, glutealno in na stegnih $(3,17)$. Lahko imajo nazobčane, zvezdi podobne robove, ali pa so v obliki črke H (14). V Tabeli 2 navajamo deleže razporeditve kožnih sprememb po predelih telesa. Spremembe na trupu so bolj pogoste pri znotrajmaternični smrti pred 14. tednom nosečnosti, spremembe na udih pa po 14. tednu (17). Občasno so lahko kožne spremembe ob rojstvu že zaceljene in se kažejo kot simetrične atrofične brazgotine. Histološki pregled tkiva pokaže tanek epitel brez kožnih adneksov, ki je nadomestil epidermis. $V$ dermisu najdemo fibrozo in odsotnost elastičnih vlaken (18).

Aplazija kože naj bi nastala zaradi motnje prekrvitve. Po eni od teorij pride do akutne hipovolemije živega dvojčka zaradi sprememb v tlakih in uporih posteljice ter feto-fetalne transfuzije $v$ odmrli plod $(1,18)$. Ob motnji prekrvitve se v simetričnih (t. i. watershed) področjih razvije aplazija kože, včasih pa ishemija prizadene tudi prebavni in živčni sistem $(1,17)$. Po drugi teoriji so za motnjo prekrvitve krivi krvni strdki, ki nastanejo zaradi smrti ploda $(17,19)$. Ob dvojčkovi smrti naj bi namreč preko žilnih anastomoz v posteljici prišlo do prenosa trombogenega materiala in sproženja kaskade diseminirane intravaskularne koagulacije pri živem plodu $(18,19)$. Tretja teorija pravi, da zaradi feto-fetalnih transfuzij pride do ishemije pri obeh dvojčkih, a jo preživi samo eden $(18,20,21)$.

Ta tip PAK ima dobro napoved izida bolezni, razen če so pridružene tudi druge prirojene nepravilnosti, na primer atrezija črevesa ali možganski infarkti. Opisani so tudi primeri s pridruženimi pljučnimi nepravilnostmi, distrofijo nohtov, razvojnim zaostankom, spastično paralizo, eno umbilikalno arterijo, subependimalno nodularno heterotopijo in posteriorno parietalno kortikalno displazijo (18). Pri otrocih s to obliko PAK zato priporočamo slikovno diagnosticiranje osrednjega živčnega sistema (18).

Ta oblika PAK ni povezana z genetskimi nepravilnostmi. Primeri so sporadični in ne predstavljajo večjega tveganja za naslednje nosečnosti (17).

\section{Bulozna epidermoliza kot vzrok PAK}

Pri obravnavi multiplih sprememb PAK na trupu in udih moramo pomisliti na bulozno epidermolizo (EB) novorojenčka, ki je uvrščena $v$ šesto skupino klasifikacije po Friednu $(4,22)$. Pred rojstvom zaradi otrokovega premikanja in pritiska na steno maternice pride do odstopa krhke kože in nastanka mehurjev, ki se oluščijo in nastane kožni defekt (1).

Bulozna epidermoliza novorojenčka je redek podtip distrofične bulozne epidermolize, ki največkrat spontano izzveni v prvem letu življenja $(23,24)$. Mehurji se spontano zacelijo s fibrozacijo kože ali celo brez brazgotin. Bolezen je posledica mutacije gena za kolagen VII (COLA7A1), ki kožno bazalno membrano pritrjuje na podkožje $(25,26)$. Dedovanje je avtosomno dominantno (AD) ali recesivno (AR) $(25,26)$. PAK je pogostejša pri AR obliki. Kožni defekti so najpogosteje simetrični in se nahajajo na spodnjih udih. Fragilnost kože vztraja na brazgotinah po PAK tudi, ko drugod po telesu že izzveni (27).

PAK in EB se lahko pojavljata tudi $v$ sklopu Bartovega sindroma, za katerega sta značilni epidermoliza kože in ustne sluznice ter odsotnost ali distrofija nohtov. Tudi tu gre za okvaro kolagena VII, ki se deduje po AD vzorcu. Pogosto je pridružena atrezija pilorusa, redkeje mišična distrofija $(1,22)$.

Pri sumu na EB je nujna opredelitev tipa EB glede na raven kožne bazalne membrane, kjer pride do odstopa kože. Glede na prizadeto plast kože EB razdelimo na glavne podtipe: EB simpleks, junkcijska EB, distrofična EB in Kindlerjev sindrom (28). Večina oblik se deduje $A D$, zato je pomembna družinska anamneza. Pri diagnosticiranju so pomembni transmisijsko elektronsko mikroskopiranje (TEM), imunofluorescentno antigensko mapiranje (IFM) in genetske preiskave. Za TEM in IFN potrebujemo z biopsijo odvzet vzorec 
kožne spremembe. Pogosteje uporabljamo metodo IFM, ki omogoča, da s protitelesi prikažemo raven, na kateri je prišlo do odstopa. Metoda je hitra ter ima visoki specifičnost in občutljivost (22).

\section{Teratogeni}

PAK je povezana tudi $z$ vplivom teratogenov in okužb med nosečnostjo, na primer z okužbami z virusom Herpes simplex in virusom Varicella zoster. Po klasifikaciji je uvrščena v osmo skupino $(1,4,29)$. Prav tako je PAK bolj pogosta pri otrocih mater, ki so med nosečnostjo uživale marihuano, alkohol ali kokain $(22,29)$. Zdravila, ki vplivajo na nastane PAK, so misoprostol, metotreksat, inhibitorji $A C E$, metimazol, benzodiazepini in valproat $(2,14,29)$.

Pazljivost je potrebna predvsem pri uporabi metimazola in karbimazola (ki se presnovi v metimazol) pri zdravljenju hipertiroidizma med nosečnostjo, $s$ katerim se srečuje $0,2 \%$ nosečnic. Izpostavljenost metimazolu v prvem trimesečju je povezana s povečano pojavnostjo PAK in drugih prirojenih hib (omfalokela, atrezija hoan, malformacije prebavil) (14). Zato med organogenezo uporabljamo propiltiouracil (PTU) in ga zaradi preprečevanja hepatotoksičnosti pri materi in plodu $v$ drugem trimesečju zamenjamo za metimazol (14).

\section{Malformacijski sindromi}

PAK se pojavlja tudi v sklopu številnih sindromov, na primer pri Gorlin-Goltzovem sindromu $z$ okvarami ektoderma (oči, koža), mezoderma (zobje, kosti) in endoderma (sluznice) $(3,29)$. PAK je prisotna tudi pri $35-50 \%$ otrok s trisomijo 13 (Patauov sindrom) $(1,4,29)$. Ostali sindromi, povezani s PAK, so Wolf-Hirschhornov sindrom, Setleisov sindrom, Johanson-Blizzardov sindrom, sindrom amnijskih trakov,
Dellemanov sindrom, Finlay-Marksov sindrom, sindrom Kabuki, mikroftalmija z linearnimi kožnimi defekti in 46XY gonadna disgeneza $(22,29)$.

\section{Travmatska etiologija PAK}

Prirojena Volkmannova ishemična kontrakura (CVIC) je redka motnja, ki nastane zaradi prehodne ishemije, običajno v zgornjem udu. Reperfuziji sledita utesnitveni sindrom ter kompresijska okvara mišic in živcev. Pri pregledu ugotavljamo enostransko kožno ulceracijo $z$ nepravilnimi robovi in ipsilateralno parezo živca. Takoj po rojstvu je prisotna flakcidna pareza, kasneje pa se razvijejo kontrakture uda $(30,22)$.

Ekstrinzični vzroki so oligohidramnij, makrosomija, večplodna nosečnost, nosečnostna sladkorna bolezen ali težka ekstrakcija med porodom $(22,30)$. Vzrok je lahko tudi hiperkoagulabilno stanje ploda $(22,30)$.

\section{Prizadetost globokih anatomskih struktur in zapleti PAK}

V približno $20 \%$ PAK so prizadete globoke anatomske strukture, na primer podkožno maščevje, mišice, kosti in možganske ovojnice (5). Pri oceni globine PAK je zelo koristna ultrazvočna preiskava (UZ), zlasti pri spremembah na glavi. Z UZ lahko v primerih, ko je ob rojstvu sprememba že fibrozirana, tudi postavimo diagnozo. $Z$ uporabo gelaste blazine lahko natančno ocenimo tudi strukture blizu površine kože ter na mestu kožne spremembe opazimo stanjšanje epidermisa in dermisa (31).

Znani dejavniki tveganja za prizadetost globokih struktur so umeščenost PAK na verteksu lobanje oz. v sredinski črti lobanje (3- do 4-krat večje tveganje), spremembe, večje od $5 \mathrm{~cm}$, prisotnost lasnega obroča ter žilna znamenja in podkožni vozliči v bližini PAK (32). Pri otrocih s temi značilnostmi priporočamo ultrazvočni pregled možganov ali magnetnoresonančno slikanje (MRI) (pri starejših od 6 mesecev). Spol in večje število sprememb PAK ne predstavljata večjega tveganja za okvaro spodaj ležečih struktur (32). Tudi membranozna PAK ne pomeni povečanega tveganja kostnih defektov, je pa pogosteje povezana $z$ disrafizmom nevralne cevi (32).

Smrtnost zaradi PAK ocenjujejo na 20-55\%, predvsem na račun velikih defektov na skalpu, ki vodijo $v$ trombozo sagitalnih sinusov, krvavitve, hidrocefalus ali okužbe, in zaradi pooperativnih zapletov $(1,17)$. Kljub veliki površini kožnih defektov je smrtnost znatno nižja pri 5. tipu (po Friednovi klasifikaciji), pri katerem se spremembe običajno nahajajo na trupu (17).

\section{Zdravljenje}

PAK lahko zdravimo konzervativno ali kirurško; o načinu se odločamo glede na velikost, globino in umeščenost spremembe. Zdravljenje rane se ne razlikuje pomembno glede na tip PAK.

Za konzervativno zdravljenje običajno uporabljamo lokalne vazelinske obloge, obloge s srebrovim sulfadiazinom, občasno tudi jodove obloge $(3,17,28)$. Pri uporabi jodovih in srebrovih oblog moramo biti previdni zaradi morebitnih neželenih učinkov, kot je hipertiroidizem (33). Za preprečevanje bakterijskih okužb uporabljamo lokalni antibiotik (mupirocin) (3). Pomembno je tudi skrbno uravnavanje temperature in vlage okolja, da preprečimo izgube tekočine skozi rane (17). Do reepitelizacije spremembe pride po približno 8 tednih, po 3-4 mesecih pa se na mestu defekta oblikuje atrofična brazgotina (33). Pri takšni vrsti zdravljenja obstaja večje tveganje krvavitve, tromboze sagitalnega sinusa, okužbe in nekroze rane (17). 

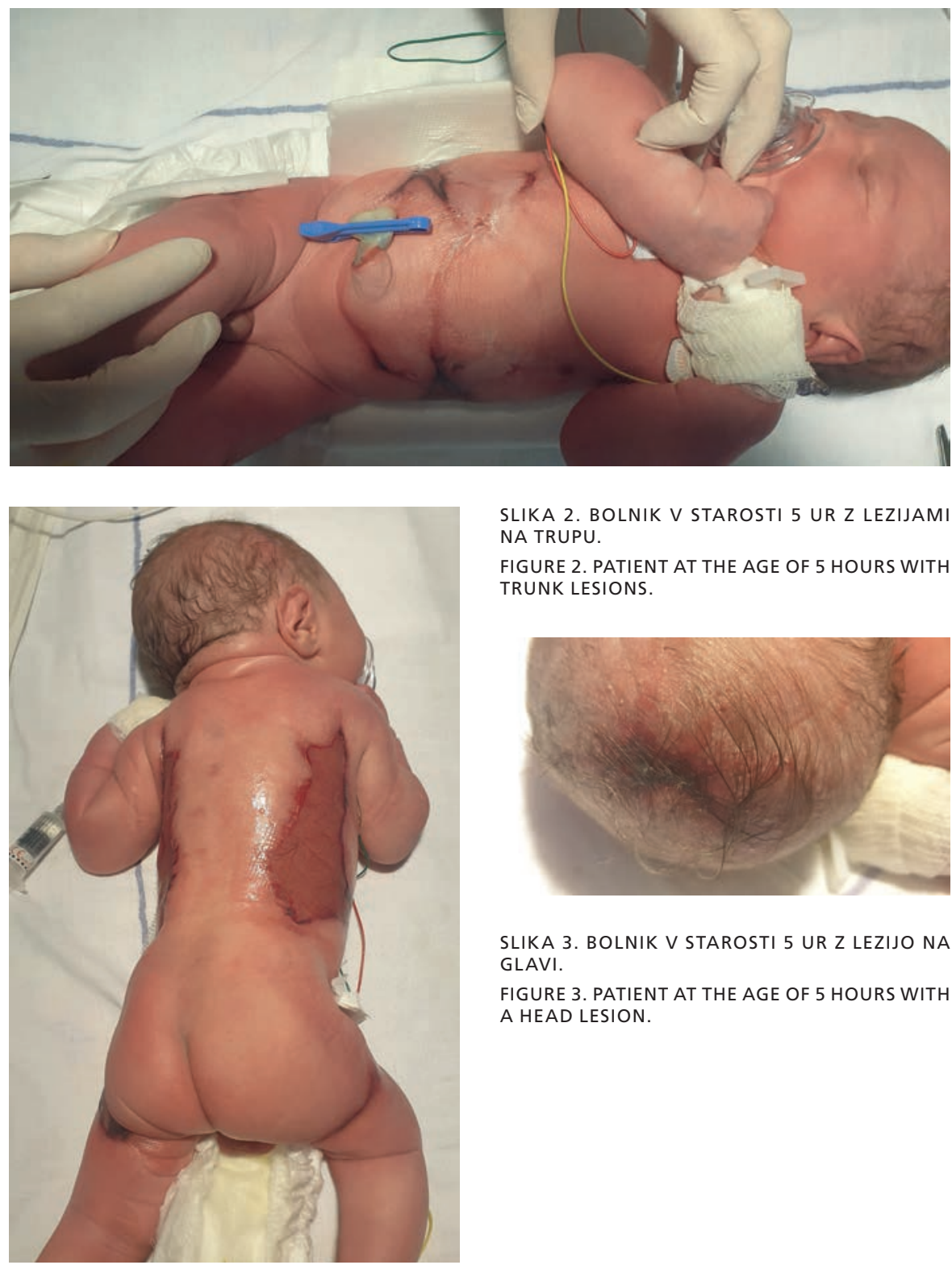

SLIKA 2. BOLNIK V STAROSTI 5 UR Z LEZIJAMI NA TRUPU.

FIGURE 2. PATIENT AT THE AGE OF 5 HOURS WITH TRUNK LESIONS.

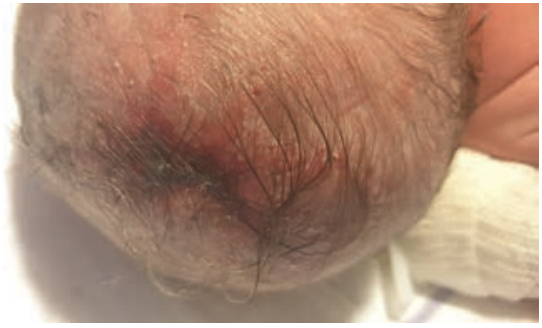

SLIKA 3. BOLNIK V STAROSTI 5 UR Z LEZIJO NA GLAVI.

FIGURE 3. PATIENT AT THE AGE OF 5 HOURS WITH A HEAD LESION.
Vendar tudi kirurške intervencije s kožnimi režnji ter kožnimi ali kostnimi presadki spremlja tveganje. Nevarne so medoperativne krvavitve, okužbe, zapleti na mestu odvzema kože, nekroze presadka in anestezijski zapleti $(3,17)$. Nekateri avtorji predlagajo kirurško zdravljenje pri spremembah, ki so večje od $24 \mathrm{~cm}$, spet drugi pri ranah, večjih od $3-4 \mathrm{~cm}(1,3,17)$. Za kirurško korekcijo se pogosteje odločamo, če so defekti na glavi, če zajemajo kost, če so izpostavljene žile (nevarnost krvavitve), možganske ovojnice ali možganski venski sinusi ter pri ponavljajočih se okužbah in neuspešni epitelizaciji ter ko velike lezije povzročajo elektrolitske motnje zaradi izgube tekočin $(2,14)$. PAK na trupu pogosto zdravimo konzervativno, tudi če so kožne spremembe velike (2).

Večina kostnih defektov na lobanji se zaceli spontano, tj. brez kirurškega posega, nekateri veliki kostni defekti pa potrebujejo takojšnjo ali odloženo kranioplastiko $(2,22)$. Če je potreben kirurški poseg, ga najpogosteje izvedemo v starosti nekaj let (22).

Pri kirurškemu zdravljenju kožnih sprememb obstajajo številne možnosti. Če defekt zahteva takojšen poseg, lahko uporabimo kožni reženj, a je pri tej obliki rekonstrukcije trajanje posega daljše in lahko povzroči večje izgube krvi, obsežne brazgotine, počasnejšo rast kosti in nekroze (2). Bolj preprosta je uporaba kožnih presadkov. Kožni presadki, ki zajemajo polno debelino kože, preprečujejo okužbe in krvavitve ter spodbujajo osifikacijo spodaj ležeče kosti (2). Pri dojenčkih pogosto uporabljamo kožne presadke, ki zajamejo le delno debelino kože, saj se pri teh presadkih koža na odvzemnem mestu obnovi brez brazgotin. Vzamemo jih običajno $z$ otrokovega hrbta. Slabost tehnike je, da se presadki lahko prirastejo na možganske ovojnice in otežijo kasnejšo kranioplastiko. Težavo zaobidemo tako, da presadek namestimo na spremembo po formaciji granulacijskega tkiva, a z odloženim posegom tvegamo okužbe v vmesnem času (2). 
Predel alopecije, ki nastane $v$ lasišču po konzervativnem ali kirurškem zdravljenju PAK na skalpu, lahko v starosti nekaj let odstranimo s tkivnimi razširjevalci (t. i. ekspanderji) (22).

\section{Algoritem obravnave}

Pri otroku s priorojeno aplazijo kože sta potrebna kompleksna obravnava in izključitev pridruženih prirojenih nepravilnosti. $V$ Tabeli 3 povzemamo obravnavo različnih tipov PAK s priporočenimi preiskavami.

\section{Predstavitev kliničnega primera}

Pet ur starega dečka so zaradi prirojene aplazije kože iz področne porodnišnice premestili na Klinični oddelek za neonatologijo Pediatrične klinike Ljubljana.

V družini niso imeli kroničnih bolezni ali prirojenih nepravilnosti. Sorojenec je zdrav. Deček je bil plod druge nosečnosti 34-letne matere s krvno skupino 0 RhD pozitivno. Nosečnost je bila plod spontane zanositve. Bila je dvoplodna z monohoriatnimi dvojčki. $\checkmark$ 14. tednu nosečnosti je eden od plodov odmrl. $V$ času dogodka se je mati dobro počutila in ni prebolevala okužbe, odmrtje pa so odkrili naključno na rednem ultrazvočnem pregledu. $V$ nadaljevanju nosečnosti ni bilo posebnosti. Deček je bil rojen po spontanem začetku poroda s popadki, po dopolnjenih 39 tednih s porodno težo 3660 $\mathrm{g}$, porodno dolžino $52 \mathrm{~cm}$ in obsegom glave $36 \mathrm{~cm}$. Ocena po Apgarjevi je bila $6 / 8 / 8$. Porod je trajal 5 ur 49 minut, razpok plodovih ovojev pa 10 minut. Plodovnica je bila mekonijska, popkovnica enkrat ovita okoli vratu, posteljica cela. Takoj po rojstvu je 12 minut potreboval spodbudo za dihanje $z$ dodatkom $30 \%$ kisika preko maske Venturi. Na trupu in udih so bile vidne kožne spremembe (Slika 1), ki so bile razporejene dokaj

\begin{tabular}{|c|c|c|}
\hline Etiologija & Tip PAK & Priporočila \\
\hline \multirow[t]{4}{*}{ razvojne motnje } & membranozna PAK na skalpu & $\begin{array}{l}\text { - MRI, če je na verteksu ali na } \\
\text { sredinski črti kalvarije } \\
\text { - MRI, če ni na sredinski črti, a ima } \\
\text { lasni obroč ali ob sumu kostni } \\
\text { defekt }\end{array}$ \\
\hline & PAK z deformacijami udov & $\begin{array}{l}\text { sum na AOS: } \\
\text { - družinska anamneza } \\
\text { - UZ glave, če je na skalpu } \\
\text { - izključitev pridruženih prebavnih, } \\
\text { srčno-žilnih in nevroloških } \\
\text { nepravilnosti (MRI, UZ trebuha, } \\
\text { ECHO) } \\
\text { - genetske preiskave }\end{array}$ \\
\hline & $\begin{array}{l}\text { PAK z bulozno epidermolizo } \\
\text { (multiple akralne spremembe) }\end{array}$ & $\begin{array}{l}\text { - genetske preiskave, kožna biopsija } \\
\text { za TEM in IFN } \\
\text { - sum na Bartov sindrom: } \\
\text { - ocena nohtov in ustne sluznice } \\
\text { - izključitev atrezije pilorusa ob } \\
\text { ustrezni klinični sliki }\end{array}$ \\
\hline & nemembranozna PAK na skalpu & $\begin{array}{l}\text { - UZ glave za izključitev kostnih } \\
\text { defektov } \\
\text { - ocena udov za izključitev AOS } \\
\text { - družinska anamneza. }\end{array}$ \\
\hline destrukcija tkiva & $\begin{array}{l}\text { nemembranozna PAK na trupu } \\
\text { ali udih }\end{array}$ & $\begin{array}{l}\text { simetrična, obojestranska: } \\
\text { - na fetus papyraceus } \\
\text { - ocena spodaj ležečih struktur in UZ } \\
\text { glave } \\
\text { enostranska: } \\
\text { - sum na CVIC } \\
\text { - ocena spodaj ležečih struktur } \\
\text { - nevrološki pregled, izključitev } \\
\text { pareze živca (morda EMG) }\end{array}$ \\
\hline
\end{tabular}

Ob prisotnosti dismorfnih značilnostih vedno opravimo genetske preiskave.

TABELA 3. OBRAVNAVA PRIROJENE APLAZIJE KOŽE $(1,22)$

Legenda: PAK - prirojena aplazija kože; AOS - Adams-Oliverjev sindrom; ECHO - ehokardiografija; MRI magnetnoresonančno slikanje; EMG - elektromiografija; CVIC - prirojena Volkmannova ishemična kontrakura; TEM - transmisijsko elektronsko mikroskopiranje; IFM - imunofluorescentno antigensko mapiranje.

TABLE 3. ALGORITHM FOR THE MANAGEMENT OF ACC $(1,22)$.

Legend: PAK - congenital skin aplasia; AOS - Adams-Oliver syndrome; ECH O - echocardiography; MRI magnetic resonance imaging; EMG - electromyography; CVIC - congenital Volkmann's ischemic contracture; TEM - transmission electron microscopy; IFM - immunofluorescent antigen mapping. 
simetrično po obeh straneh vzdolž hrbta in obojestransko subglutealno. Že nastala brazgotina je segala na sprednjo stran trupa. V ležišču lezij je bilo vidno prosevajoče žilje, na glavi centralno-parietalno pa področje vdrte kože, prekrito s suho krasto.

Ob sprejemu na naš oddelek smo ugotovili primerne vrednosti vitalnih parametrov (srčni utrip 131/min, krvni tlak $83 / 44 \mathrm{mmHg}$, telesna temperatura $36,7^{\circ} \mathrm{C}, \mathrm{SpO}_{2} 100 \%$ ). Razen kožnih sprememb je bil klinični status brez odstopanj od normalnega. Kožne spremembe niso bile videti vnete. $V$ laboratorijskih izvidih so bile vrednosti vnetnih kazalnikov negativne, vrednosti elektrolitov pa $v$ mejah normalnih. Otroka smo namestili v inkubator. Predele nerazvite kože na glavi in trupu smo zaščitili z vazelinsko mrežico, preko katere smo nanesli vpojne materiale. Zaradi boljšega celjenja ob sušenju smo kožne spremembe večkrat dnevno pustili odkrite, ko je otrok ležal na trebuhu. Negovali smo jih z negovalno zaščitno kremo (Bepanthen) ter jih zaščitili z vazelinskimi mrežicami in sterilnimi zloženci. Vsak dan smo izvajali antiseptične kopeli z milom Octenisan. V starosti 12 ur je prišlo do blagega porasta vrednosti vnetnih kazalnikov (CRP 14). Po odvzemu kužnin smo ga pričeli zdraviti s flukloksacilinom in gentamicinom v skupnem trajanju $7 \mathrm{dni}$. Iz brisa kože je pozno porasla bakterija Enterococcus faecalis, občutljiva na vse testirane antibiotike. Vrednosti vnetnih kazalnikov so se ustrezno znižale. Ostale kužnine so ostale sterilne. $\checkmark$ zdravljenje smo vključili dermatologa in kirurga plastika. Zdravili smo ga konzervativno in v nego vključili tudi dečkovo mater.

Da bi izključili prizadetost spodaj ležečih struktur, smo opravili UZ glave, ki je pokazal striatno vaskulopatijo obojestransko $v$ bazalnih ganglijih. Z UZ trebuha smo ugotovili normalne strukture. Oftalmolog je prepoznal nekoliko stanjšano mrežnico obojestransko.
Po 11 dneh bolnišničnega zdravljenja so kožne spremembe $z$ roba pričele fibrozirati. Centralno so bile občasno pod oblogami še vlažne, a brez znakov vnetja. Na suhih predelih je bilo ležišče prekrito s krasto. Levo subglutealno je bila sprememba suha, velikosti $3 \mathrm{~cm} \times 1 \mathrm{~cm}$. Brazgotinske spremembe so segale $s$ hrbta na sprednji del trupa. V domačem okolju so starši izvajali nego po navodilih. Okužbe ni imel. Do starosti dveh mesecev so bile vse kožne spremembe suhe, prekrite $z$ vezivnim tkivom. Na Slikah 1-5 prikazujemo stanje bolnikove kože v različnih obdobjih.

\section{Razpravljanje}

Glede na razporeditev kožnih sprememb in podatek o odmrtju enega od obeh plodov v začetku drugega trimesečja nosečnosti gre etiološko najverjetneje za PAK z lokalno motnjo $\checkmark$ prekrvitvi posteljice ob sindromu papirnatega dvojčka (lat. fetus papyraceus), ki po Friednu sodi v 5. skupino. Ob porodu preživelega ploda se je porodil v mumificirani, sploščeni obliki. Prisotna je bila tipično simetrična in lokacijska razporeditev kožnih sprememb v različnih fazah celjenja. Zdelo se je, da je brazgotinjenje za otroka neprijetno. Dodatnih prirojenih nepravilnosti nismo ugotovili. Kožni defekt na skalpu je bil majhen, zaceljen in ni zajemal globljih struktur. Zdravljenje je bilo konzervativno in po osmih tednih je prišlo do popolne zacelitve. Ker je po podatkih iz literature primer sporadičen in ne pomeni večjega tveganja za naslednje nosečnosti, se za genetsko svetovanje nismo odločili.

\section{Zaključek}

Etiološka raznolikost nastanka PAK in nepredvidljivost prizadetosti globljih struktur ali pridruženost drugih anomalij sta glavni izhodišči pri obravnavi te redke kožne spremembe. O obravnavi PAK na skalpu smernice niso dorečene, zato o zdravljenju presojamo individualno. $V$ vseh primerih je smiselno, da upoštevamo konzervativne ukrepe s sterilnim prekrivanjem in nego kožnih sprememb. Če je potrebna kirurška obravnava, v multidisciplinarno obravnavo vključimo neonatologa, radiologa, nevrokirurga, kirurga plastika in dermatologa.

\section{Literatura}

1. Browning JC. Aplasia cutis congenita: approach to evaluation and management. Dermatol Ther 2013; 26(6): 439-44

2. Silberstein E, Pagkalos VA, Landau $D$, et al. Aplasia cutis congenita: clinical management and a new classification system. Plas Reconstr Surg 2014; 134(5): 766e-74e

3. Mesrati $\mathrm{H}$, Amouri M, Chaaben $\mathrm{H}$, Masmoudi A, Boudaya S, Turki H. Aplasia cutis congenita: report of 22 cases. Int J Dermatol 2015; 54(12): $1370-5$

4. Frieden IJ. Aplasia cutis congenita: a clinical review and proposal for classification. J Am Acad Dermatol. 1986; 14(4): 646-60.

5. Mannino FL, Jones KL, Benirschke K. Congenital skin defects and fetus papyraceus. J Pediatr 1977; 91(4): 559-64

6. Drolet BA, Baselga E, Gosain AK, Levy ML, Esterly NB. Preauricular skin defects. A consequence of a persistent ectodermal groove. Arch Dermatol. 1997; 133(12): 1551-4.

7. Drolet B, Prendiville J, Golden J, Enjolras O, Esterly NB. ,Membranous aplasia cutis' with hair collars. Congenital absence of skin or neuroectodermal defect? Arch Dermatol. 1995; 131(12): $1427-31$

8. Drolet BA, Clowry L Jr, McTigue MK, Esterly NB. The hair collar sign: marker for cranial dysraphism. Pediatrics. 1995; 96: 309-13.

9. Adams FH, Oliver CP. Hereditary deformities in man: due to arrested development. J Hered 1945; 36: 3-7.

10. Hassed S, Li S, Mulvihill J, Aston C, Palmer S. Adams-Oliver syndrome review of the literature: Refining the diagnostic phenotype. Am J Med Genet A 2017; 173(3): 790-800

11. Narang T, Kanwar AJ, Dogra S. Adams-Oliver syndrome: a sporadic occurrence with minimal disease expression. Pediatr Dermatol. 2008; 25(1): 115-6.

12. Southgate $L$, Sukalo $M$, Karountzos AS, et al Haploinsufficiency of the NOTCH1 receptor as a cause of Adams-Oliver syndrome with variable cardiac anomalies. Circ Cardiovasc Genet 2015; 8(4): 572-581.

13. Baskar S, Kulkarni ML, Kulkarni AM Vittalrao S, Kulkarni PM. Adams-Oliver syndrome: additions to the clinical features and possible role of BMP pathway. Am J Med Genet A 2009: 149A (8): 1678-84. 
14. Uzuner C, Seeho SKM, Smith CJ. Aplasia cutis congenita with foetus papyraceus: Case report and review of the literature. J Obstet Gynaecol 2017; 37(6): 811.

15. Dror Y, Gelman-Kohan Z, Hagai Z, Juster -Reicher A, Cohen RN, Mogilner B. 1994. Aplasia cutis congenita, elevated alpha-fetoprotein, and a distinct amniotic fluid acetylcholinesterase electrophoretic band. Am J Perinatol 1994; 11:149-52.

16. Mannino FL, Jones KL, Benirschke K. Congenital skin defects and fetus papyraceus. J Pediatr. 1977; 91(4): 559-64.

17. Perry BM, Maughan CB, Crosby MS, Hadenfeld SD. Aplasia cutis congenita type V: a case report and review of the literature. Int J Dermatol 2017; 56(6): e118-e121.

18. Pieretti ML, Alcalá R, Boggio P, et al. Aplasia cutis congenita associated with fetus papyraceus. Pediatr Dermatol 2015; 32(6): 858-61.

19. Schaffer JV, Popiolek DA, Orlow SJ. Symmetrical truncal cutis aplasia following multifetal reduction of a sextuplet pregnancy. J Pediatr 2008; 153: 860-3.

20. Pharoah PO. Multiple births and aplasia cutis. J Pediatr. 2009; 155(4): 598; author reply 598-9.

21. Gonen R. The origin of brain lesions in survivors of twin gestations complicated by fetal death. Am J Obstet Gynecol 1991; 165 : 1897-8.22.

22. Humphrey S, Hu X, Adamson K, Schaus A, Jensen J, Drolet B. A practical approach to the evaluation and treatment of an infant with aplasia cutis congenita. J Perinatol 2018; 38(2) 110-7.

23. Hashimoto K, Matsumoto M, lacobelli D. Transient bullous dermolysis of the newborn Arch Dermatol 1985; 121: 1429-1438. 2.

24. Fine JD, Bruckner-Tuderman L, Eady RA, Bauer EA, Bauer JW, Has C, et al. Inherited epidermolysis bullosa: updated recommendations on diagnosis and classification. J Am Acad Dermatol 2014; 70: 1103-26.

25. Christiano AM, Fine JD, Uitto J. Genetic basis of dominantly inherited transient bullous dermolysis of the newborn: a splice site mutation in the type VII collagen gene. J Invest Dermatol 1997; 109: 811-4.

26. Hammami-Hauasli N, Raghunath $M$, Küster W, BrucknerTuderman L. Transient bullous dermolysis of the newborn associated with compound heterozygosity for recessive and dominant COL7A1 mutations. J Invest Dermatol 1998; 111: 1214-9.

27. Diociaiuti A, Castiglia D, Giancristoforo S, et al. Frequent occurrence of aplasia cutis congenita in bullous dermolysis of the newborn. Acta Derm Venereol 2016; 96(6): 784-7.

28. Hribernik I, Despodovska Pejkov D, Dragoš V. Obravnava novorojenčka z dedno bulozno epidermolizo. Slov Pediatr 2016; 23: 31-9.

29. Brzezinski P, Pinteala T, Chiriac AE, Foia L, Chiriac A. Aplasia cutis congenita of the scalp -what are the steps to be followed? Case report and review of the literature. An Bras Dermatol 2015; 90(1): 100-3.

30. Cham PM, Drolet BA, Segura AD, Esterly NB. Congenital Volkmann ischaemic contracture: a case report and review. Br J Dermatol. 2004 Feb; 150(2): 357-63.

31. Hioki T, Takama H, Makita S, Akiyama M. Infant bald patch: ultrasonographic diagnosis of aplasia cutis congenita. J Eur Acad of Dermatol and Venereol 2017; 31(6): e276-7.

32. Patel DP, Castelo-Soccio L, Yan AC. Aplasia cutis congenita: Evaluation of signs suggesting extracutaneous involvement. Pediatr Dermatol. 2018; 35(1): e59-61.

33. Morrow D, Schelonka R, Krol A, Davies M, Kuang A. Type $V$ aplasia cutis congenita: case report, review of the literature, and proposed treatment algorithm. Pediatr Dermatol 2013; 30(6): e208-3.

Aida Zečkanović, dr. med. Univerzitetni klinični center Ljubljana, Ljubljana, Slovenija

Sandra Cerar, dr. med. (kontaktna oseba / contact person) Klinični oddelek za neonatologijo, Pediatrična klinika, Univerzitetni klinični center Ljubljana, Ljubljana, Slovenija

prispelo / received: 19. 10. 2020

sprejeto / accepted: 8. 12. 2020

Zečkanović A, Cerar S. Prirojena aplazija kože. Slov Pediatr 2021; 28(1): 30-38. https://doi. org/10.38031/slovpediatr-2021-1-05. 